\title{
MALESIAN AND AUSTRALIAN TOURNEFORTIA TRANSFERRED TO HELIOTROPIUM AND NOTES ON DELIMITATION OF BORAGINACEAE
}

\author{
L.A. CRAVEN \\ Australian National Herbarium, CPBR, CSIRO Plant Industry, \\ G.P.O. Box 1600, Canberra, ACT 2601, Australia
}

SUMMARY

Boraginaceae is expanded to comprise seven subfamilies, two of which are based on Hydrophyllaceae and Lennoaceae, respectively. The type species of Tournefortia sect. Tournefortia is transferred to Heliotropium, as are its Malesian-Australian representatives.

Key words: Heliotropium, Tournefortia, Boraginaceae, Lennoaceae, Malesia, Australia.

\section{INTRODUCTION}

The Flora of Australia account of Boraginaceae is planned for publication in 2005 (A. Wilson, pers. comm.). As the present author is contributing the treatment for Heliotropium L. to that series, it has been necessary to consider some recent publications on the family.

\section{LIMITS OF THE FAMILY BORAGINACEAE}

A starting point may conveniently be made with Melchior (1964) who grouped Boraginaceae with Hydrophyllaceae and Lennoaceae in the suborder ('Unterreihe') Boraginineae in the order ('Reihe') Tubiflorae. Boraginaceae is a widespread family and has about 2300 species and about 130 genera assigned to five subfamilies: Boraginoideae, Cordioideae, Ehretioideae, Heliotropioideae and Wellstedioideae (Mabberley, 1997). Hydrophyllaceae is also widespread and has about 270 species in 18 genera (Mabberley, 1997). Lennoaceae is a family restricted to the New World and consists of four species of root parasites assigned to two genera (Mabberley, 1997). Flora of Australia uses the Cronquist (1981) classification of flowering plants as the basis for family recognition and treatment, albeit with some minor departures in recent years (A. Orchard, pers. comm.). Insofar as Boraginaceae is concerned, Cronquist (1981) adopted a fairly traditional circumscription, with Hydrophyllaceae assigned to Solanales and Boraginaceae and Lennoaceae to the closely related Lamiales. However, despite placing them in separate orders, he acknowledged the existence of a relationship between Boraginaceae and Hydrophyllaceae (Cronquist, 1981: 908) but did not provide details. A useful and concise enumeration of the diagnostic morphological features of Boraginaceae (including the five subfamilies), Hydrophyllaceae and Lennoaceae is given in Mabberley (1997). 
Taking advantage of an accumulation of information in recent years, derived from analysis of genome data and the more traditional sources of data such as morphology and anatomy, the Angiosperm Phylogeny Group (APG) in 1998 published a suprafamilial classification of flowering plants (APG, 1998). In this classification, the Boraginaceae were placed in the informal group Euasterids I (a group including the orders with which the Boraginaceae previously have been associated, i.e. Lamiales and Solanales) but were not assigned to an order. The families Hydrophyllaceae and Lennoaceae were referred by the APG (1998) to Boraginaceae. In a subsequent paper, the APG (2003) repeated their 1998 placement of the Boraginaceae (incl. Hydrophyllaceae and Lennoaceae) with the comment that there was still no clear placement of Boraginaceae in spite of several independent analyses of sizeable data sets. Nor did Soltis et al. (2000) find in their studies that Boraginaceae grouped unequivocally. Ferguson (1999) studied the relationships of Hydrophyllaceae using $n d h F$ sequence data and found that the 'core' Hydrophyllaceae nested into Boraginaceae s.l. with one species, Codon schenckii Schinz, nesting separately from the core Hydrophyllaceae and with the position of Hydrolea L. being unresolved. Hydrolea is now placed in a distinct family, Hydroleaceae Bercht. \& J. Presl, in the Solanales (APG, 2003).

Not all contemporary workers have accepted the combining of Hydrophyllaceae and Lennoaceae with Boraginaceae, however, and not all have accepted a broad circumscription of the latter family, instead treating it as consisting of five families, i.e. Boraginaceae s.s., Cordiaceae, Ehretiaceae, Heliotropiaceae and Wellstediaceae. Gottschling et al. (2001) utilised ITS1 data in a phylogenetic study of Boraginaceae s.l. plus Hydrophyllaceae and Lennoaceae (but not including Wellstedia Balf.f. as material was not available). In their results, Lennoaceae is the sister taxon to Ehretiaceae, and Hydrophyllaceae is the sister taxon to a clade comprising Heliotropiaceae, Cordiaceae, Ehretiaceae and Lennoaceae. The last five taxa form a clade sister to Boraginaceae s.s. Based upon the results of Gottschling et al. (2001), it seems that Hydrophyllaceae and Lennoaceae are appropriately placed with the four elements traditionally included in Boraginaceae.

It is my belief that recognition of a single family, i.e. Boraginaceae, as was adopted by the APG (1998, 2003), will serve the producers and users of botanical information better than recognising seven families. To reflect their respective identities and maintain comparability with the other subfamilies of Boraginaceae, Hydrophyllaceae and Lennoaceae should be treated at the rank of subfamily within Boraginaceae. The evolutionary position of Wellstedioideae needs to be determined by analysis of molecular sequence data; its continued taxonomic acceptance is conditional upon its being supported as a comparably distinct clade within Boraginaceae. With this caveat in mind, the seven subfamilies of Boraginaceae are as follows: Boraginoideae Arn. (1832) 122. Type: Borago L. - Cordioideae Link (1829) 569. Type: Cordia L. - Ehretioideae (Mart. ex Lindl.) Arn. (1832) 122. Type: Ehretia P. Browne. - Heliotropioideae (Schrad.) Arn. (1832) 122. Type: Heliotropium L. - Hydrophylloideae (R. Br.) Burnett (1835) 1005-1007, 1095, 1105. Type: Hydrophyllum L. - Lennooideae (Solms) Craven (see below). Type: Lennoa La Llave \& Lex. — Wellstedioideae Pilg. (1912). Type: Wellstedia Balf.f. 


\section{THE STATUS OF TOURNEFORTIA}

The conventional circumscription of Heliotropium follows Johnston (1928) whose thorough studies of Boraginaceae have provided a foundation for its subsequent students. [Johnston's publications, and the many taxa he treated, recently have been indexed by Hilger \& Zippel (2001).] The most recent comprehensive account of Heliotropium is that of Förther who treated the sections in detail, and enumerated the species of the genus as he defined it (Förther, 1998). Förther essentially maintained the traditional circumscription of Heliotropium with the excision of several species into three small genera, i.e. Hilgeria Förther, Nogalia Verdc. and Schleidenia Endl. These are characterised as follows: Hilgeria: mat-forming herb, single-flowered, peduncle elongating in fruit to exceed the subtending leaf, fruit splitting into mericarps; Nogalia: weak succulent herb or subshrub, branchlets densely leaved, calyx lobes broad and rounded, fruit entire and drupaceous; Schleidenia: decumbent annual or short-lived perennial, anthers apically hairy, fruit entire and drupaceous. In Förther's (1998) classification of Heliotropioideae, the subfamily comprised eight genera: Argusia Boehm., Ceballosia G. Kunkel ex Förther, Heliotropium L., Hilgeria Förther, Ixorhea Fenzl, Nogalia Verdc., Schleidenia Endl. and Tournefortia L.

Förther's schema has been challenged by analysis of $\operatorname{trnL}$ and ITS1 sequence data (Diane et al., 2002; Diane, 2003; Hilger \& Diane, 2003). In particular, Diane (2003) and Hilger \& Diane (2003) effectively demonstrated that Argusia, Ceballosia, Nogalia and most of Tournefortia nested in a well-supported clade (comprising clades HELIOTHAMNUS, HELIOTROPIUM I, HELIOTROPIUM II) that included the nomenclatural type of Heliotropium (i.e. H. europaeum L.). Hilgeria and Schleidenia nested into a well-supported clade (EUPLOCA) based on Heliotropium sect. Orthostachys sensu Johnston (1928) and most contemporary authors. Clade EUPLOCA was sister to a clade (MYRIOPUS) that equates to Tournefortia sect. Cyphocyema I.M. Johnst., and Ixorhea (clade IXORHEA) was sister to the clade EUPLOCA-MYRIOPUS. Diane (2003) and Hilger \& Diane (2003) proposed that Boraginaceae subfam. Heliotropioideae (as Heliotropiaceae) be redefined to comprise five genera: Euploca Nutt., Heliotropium L., Ixorhea Fenzl, Myriopus Small, and Tournefortia L.

Because of the lack of resolution of clade HELIOTROPIUM I, i.e. the clade including T. sect. Tournefortia, Diane (2003) and Hilger \& Diane (2003) advocated retaining Tournefortia s.s. until the situation is clarified. They did state, however, that "the species of Tournefortia sect. Tournefortia warrant incorporation into the genus Heliotropium" (Hilger \& Diane, 2003: 45). Tournefortia is well represented in Central and South America but there is no recent taxonomic revision of the many species that occur there and an 'automatic' transfer of the American species to Heliotropium should not occur before at least a review of their taxonomy. For regions for which recent revisions or reviews of $T$. sect. Tournefortia exist, on the other hand, there seems to be no valid reason preventing new combinations being made in Heliotropium. This is the case in Malesia (Riedl, 1997) and Australia (Randell \& Craven, in press) where the species concerned have been recently revised. Relatively few species of Tournefortia occur in the Malesian-Australian region and the lack of a formal infrageneric classification to accommodate them is not an impediment to making the necessary alignment to their generic nomenclature. In the case of American species of Tournefortia sect. Tournefortia, until the necessary species level revision had been conducted, there will not be names 
available in Heliotropium. In the interim, authors can either continue to use the name in Tournefortia or they can adopt an informal format such as citing "Heliotropium sp. (Tournefortia [epithet authority])". Of greater concern is the taxonomic status of clade EUPLOCA. During my ongoing investigations of the Australian indigenous and naturalised species of Heliotropium as the genus is traditionally circumscribed (Craven, 1996, in press), I have formed the view that they are appropriately placed in the same genus. Rather than split what is, relative to the rest of Boraginaceae, a very natural group, I prefer to recognise a single genus for these species, i.e. Heliotropium. The studies of Diane et al. (2002), Diane (2003) and Hilger and Diane (2003) now lead me to the conclusion that Heliotropium should be expanded to include all members of Heliotropioideae.

The species treated by Riedl (1997) as Tournefortia in the Flora Malesiana account are enumerated below as species of Heliotropium; this includes the three Australian species as they also occur in Malesia. To preserve the name Heliotropium against the less speciose Tournefortia, the formal transfers of the latter genus and its type species to Heliotropium are also effected.

Boraginaceae subfam. Lennooideae (Solms) Craven, comb. nov.

Basionym: Lennoaceae Solms (1870) 174. - Type: Lennoa La Llave \& Lex.

\section{HELIOTROPIUM}

Heliotropium L. (1753) 130. - Type (fide Britton \& Brown (1913) 73): Heliotropium europaeum L. Tournefortia L. (1753) 140. - Type (fide Britton \& Millspaugh (1920) 361): Tournefortia hirsutissima L. (Heliotropium verdcourtii Craven), typ. cons. prop.

Note - The names Heliotropium and Tournefortia were published by Linnaeus (1753) in the same work and hence have equal priority. The formal transfer of Tournefortia into the synonymy of Heliotropium is effected here to maximise nomenclatural stability, given that the latter genus is more speciose and more widely distributed than Tournefortia and least disruption will occur by accepting the name Heliotropium over Tournefortia.

\section{Heliotropium verdcourtii Craven, nom. nov.}

Replaced synonym: Tournefortia hirsutissima L. (1753) 140. - Type (fide Johnston (1949) 133): "Tournefortia caule hirsuto", Plumier in Burman, Pl. Amer. (1760) t. 229, typ. cons. prop.

Notes -1 . This New World species, the nomenclatural type of Tournefortia, is formally transferred to Heliotropium and a name made available for it in the latter genus now that Tournefortia is placed in subordinate synonymy.

2. The lectotypification by Johnston (1949) has been accepted by Jarvis et al. (1993) and is followed here.

3. A new epithet is required in Heliotropium due to the prior name H. hirsutissimum Grauer (1784). The new epithet has been selected to commemorate Bernard Verdcourt whose prolific published research (Verdcourt, 1997, 2002) includes several contributions on Boraginaceae, notably the account of the family for Flora of Tropical East Africa (Verdcourt, 1991). 
2. Heliotropium biblianum Craven, nom. nov.

Replaced synonym: Tournefortia tetrandra Blume (1826) 845. - Type: Blume s.n. (holo L n.v.), Java.

Notes - 1. A new name is required in Heliotropium due to the prior name H. tetrandrum Lour. (1790). The new epithet is derived arbitrarily from the Greek, biblion, a diminutive of biblos, book, scroll, paper, and is intended to honour botanical bibliographers. When conducting systematic research, I am often reminded of the enormous debt we owe to those persons who prepare bibliographies of plant names, collectors, publications, etc. and it is high time I acknowledged this in a more enduring manner.

2. See Riedl (1997) for additional taxonomic synonyms.

\section{Heliotropium buruense Craven, nom. nov.}

Replaced synonym: Tournefortia oppositifolia Riedl (1996) 444. - Type: Van Balgooy 4885 (holo L n.v.), Indonesia, Maluku, Buru, NW Buru, SE from Bara, Waeduna.

Note - A new epithet is required in Heliotropium due to the prior name H. oppositifolium Ruiz \& Pav. (1799). The epithet selected is derived from the name of the island Buru, the only region in which this species is known to occur.

\section{Heliotropium foertherianum Diane \& Hilger}

Heliotropium foertherianum Diane \& Hilger in Hilger \& Diane (2003) 46. - Tournefortia argentea L.f. (1781) 133. - Type: Koenig s.n. (holo LINN n.v.), Sri Lanka.

Notes -1 . This common shrub or small tree species of the Indo-western Pacific region is sometimes treated under Argusia Boehm. or Messerschmidia L. ex Hebenstr. As H. argenteum is pre-empted in Heliotropium by H. argenteum Lehm. (1818), Hilger $\&$ Diane (2003) provided a new name for the species.

2. See Riedl (1997) for additional taxonomic synonyms.

5. Heliotropium luzonicum (I.M. Johnst.) Craven, comb. nov.

Basionym: Tournefortia luzonica I.M. Johnst. (1935) 156. - Type: Adduru 237 (holo A; iso K, both n.v.), Luzon, Cagayan Province, vicinity of Peñablanca.

\section{a. subsp. luzonicum}

b. subsp. angustissimum (Riedl) Craven, comb. nov.

Basionym: Tournefortia luzonica subsp. angustissima Riedl (1996) 443. - Type: Ridsdale 1477 (holo L n.v.), Philippines, Luzon, Zambales Province, Santa Cruz, Acoje Mine concession area.

c. subsp. sublucens (I.M. Johnst.) Craven, comb. nov.

Basionym: Tournefortia luzonica var. sublucens I.M. Johnst. (1935) 157. - Tournefortia luzonica subsp. sublucens (I.M. Johnst.) Riedl (1996) 443. - Type: Ramos \& Edaño 44553 (holo A; iso B, BM, K, all n.v.), Luzon, Zambales Province, Anuling. 
6. Heliotropium muelleri (I.M. Johnst.) Craven, comb. nov.

Basionym: Tournefortia muelleri I.M. Johnst. (1935) 157. — Tournefortia mollis F. Muell. (1858) 59, nom. illeg., non Bertoloni (1851) 186. - Type: Mueller s.n. (holo MEL; iso K n.v.), Australia, ad ripas fluvii Burdekin.

\section{Heliotropium riedlii Craven, nom. nov.}

Replaced synonym: Tournefortia minutiflora Riedl (1996) 443. - Type: Ivalaoa UPNG 7752 (holo L; iso K, LAE, UPNG, all n.v.), Papua New Guinea, Gulf Province, near Lelefiru, Miaru Mareka Point near Meporo River.

Note - A new epithet is required in Heliotropium due to the prior name H. minutiflorum Bunge (Von Bunge, 1869). The new epithet honours Harald Udo von Riedl (1936-), a student of Boraginaceae and author of the Flora Malesiana account of this family (Riedl, 1997).

\section{Heliotropium sarmentosum (Lam.) Craven, comb. nov.}

Basionym: Tournefortia sarmentosa Lam. (1792) 416. - Type: leg. ign. s.n. (holo P n.v.), the type, fide Johnston (1935), is labelled "colitur in horto regio insulae Franciae" and "de M. Sonnerat", and represents a Malesian form of the species.

Note - See Riedl (1997) for additional taxonomic synonyms.

\section{ACKNOWLEDGEMENTS}

Prof. Hartmut Hilger is thanked for the generous and speedy provision of publications, and especially for presenting a seminar in Canberra on the phylogenetic studies of Boraginaceae s.l. being conducted in his laboratory. Annette Wilson, the then Australian Botanical Liaison Officer, Kew, at rather short notice obtained copies of several references not held in Canberra. Prof. James Reveal kindly provided information on relevant subfamilial names. An anonymous reviewer drew attention to some unintended mishaps in citation. The Directors and/or Curators of CANB and MEL are thanked for the opportunity to study specimens in their care.

\section{REFERENCES}

Angiosperm Phylogeny Group. 1998. An ordinal classification for the families of flowering plants. Ann. Missouri Bot. Gard. 85: 531-553.

Angiosperm Phylogeny Group. 2003. An update of the Angiosperm Phylogeny Group classification for the orders and families of flowering plants: APG II. Bot. J. Linn. Soc 141: 399-436.

Arnott, G.A.W. 1832. Botany. In: M. Napier (ed.), Encycl. Brit. ed. 7, 5: 30-145.

Bertoloni, A. 1851. Tournefortia mollis. Mem. Reale Accad. Sci. Ist. Bologna, ser. 2, 3: 186.

Blume, C.L. 1826. Tournefortia tetrandra. Bijdr.: 845. Lands Drukkerij, Batavia.

Britton, N.L. \& A. Brown. 1913. Heliotropium. In: Ill. Fl. N. U.S., ed. 2, 3: 73.

Britton, N.L. \& C.F. Millspaugh. 1920. Tournefortia. Bahama Fl.: 361.

Burnett, G.T. 1835. Outlines of botany. Renshaw, London.

Craven, L.A. 1996. A taxonomic revision of Heliotropium (Boraginaceae) in Australia. Austral. Syst. Bot. 9: 521-657.

Craven, L.A. In press. Seven new species of Heliotropium (Boraginaceae) from the monsoon and arid zones of Australia. The Beagle.

Cronquist, A. 1981. An integrated system of classification of flowering plants. Columbia University Press, New York. 
De Lamarck, J.B.A.P.M. 1792. Tournefortia sarmentosa. Tabl. Encycl. 1: 416.

De Loureiro, J. 1790. Heliotropium tetrandrum. In: Fl. Cochinch. 1: 103.

Diane, N. 2003. Systematic analysis of the Heliotropiaceae based on molecular and morphological-anatomical data. PhD thesis, FU Berlin. URL: http://www.diss.fu-berlin.de/2003/197/index.html

Diane, N., H. Förther \& H.H. Hilger. 2002. A systematic analysis of Heliotropium, Tournefortia, and allied taxa of the Heliotropiaceae (Boraginales) based on ITS1 sequences and morphological data. Amer. J. Bot. 89: 287-295.

Ferguson, D.M. 1999. Phylogenetic analysis and relationships in Hydrophyllaceae based on ndhF sequence data. Syst. Bot. 23: 253-268.

Förther, H. 1998. Die infragenerische Gliederung der Gattung Heliotropium L. und ihre Stellung innerhalb der subfam. Heliotropioideae (Schrad.) Arn. (Boraginaceae). Sendtnera 5: 35-241.

Gottschling, M., H.H. Hilger, M. Wolf \& N. Diane. 2001. Secondary structure of the ITS1 transcript and its application in a reconstruction of the phylogeny of Boraginales. Pl. Biol. 3: 629-636.

Grauer, S. 1784. Heliotropium hirsutissimum. Pl. Min. Cogn. Dec. 1. Kiel.

Hilger, H.H. \& N. Diane. 2003. A systematic analysis of Heliotropiaceae (Boraginales) based on trnL and ITS1 sequence data. Bot. Jahrb. Syst. 125: 19-51.

Hilger, H.H. \& E. Zippel. 2001. Studies in the Boraginaceae - An index to the publications of Ivan M. Johnston dealing with the borage family. Haussknechtia, Beih. 11: 1-151.

Jarvis, C.E., F.R. Barrie, D. M. Allan \& J.R. Reveal. 1993. A list of Linnaean generic names and their types. Regnum Veg. 127: 94-95.

Johnston, I.M. 1928. Studies in the Boraginaceae,VII. Contr. Gray Herb. 81: 3-83.

Johnston, I.M. 1935. Studies in the Boraginaceae, XI. J. Arnold Arbor. 16: 145-205.

Johnston, I.M. 1949. Studies in the Boraginaceae, XVIII. J. Arnold Arbor. 30: 111-138.

Lehmann, J.G.C. 1818. Heliotropium argenteum. Pl. Asperif. Nucif.: 73. Dümmler, Berlin.

Link, J.H.F. 1829. Cordiaceae. Handbuch 1: 569.

Linnaeus, C. 1753. Heliotropium, Tournefortia. In: Sp. Pl. 1: 130-131, 140-141.

Linnaeus, C. 1781. Tournefortia argentea. Suppl. Pl.: 133. Braunschweig.

Mabberley, D. J. 1997. The Plant-book. Cambridge University Press, Cambridge.

Melchior, H. 1964. A. Engler's Syllabus der Pflanzenfamilien. Gebrüder Borntraeger, Berlin.

Pilger, R. 1912. Die Gattung Wellstedia in Südwestafrika. Bot. Jahrb. Syst. 46: 558-561.

Randell, B.R. \& L. A. Craven. In press. Boraginaceae. In: Fl. Australia 30B.

Riedl, H. 1996. New taxa in the genus Tournefortia (Boraginaceae) from the Malesian region. Blumea 41: 443-444.

Riedl, H. 1997. Boraginaceae. In: C. Kalkman et al. (eds), Fl. Males., Ser. 1, Spermat. 13: 43-144. Rijksherbarium/Hortus Botanicus, Leiden.

Ruiz, H. \& J. Pavon. 1799. Heliotropium oppositifolium. In: Fl. Peruv. [Ruiz \& Pavon] 2: 2, t. 108 b.

Soltis, D.E., P.S. Soltis, M.W. Chase, M.E. Mort, D.C. Albach, M. Zanis, V. Savolainen, W.H. Hahn, S.B. Hoot, M.F. Fay, M. Axtell, S.M. Swensen, L.M. Prince, W.J. Kress, K.C. Nixon \& J.S. Farris. 2000. Angiosperm phylogeny inferred from 18s rDNA, rbcL, and atpB sequences. Bot. J. Linn. Soc. 133: 381-461.

Verdcourt, B. 1991. Boraginaceae. In: R.M. Polhill (ed.), Fl. Trop. E. Afr. Balkema, Rotterdam \& Brookfield.

Verdcourt, B. 1997. A list of publications and new taxa described (1936-1996). The Author, Maidenhead, Berkshire.

Verdcourt, B. 2002. A list of publications and new taxa described, Supplement 1 (1997-2001). The Author, Maidenhead, Berkshire.

Von Bunge, A. A. 1869. Heliotropium minutiflorum. Bull. Soc. Imp. Naturalistes Moscou 42: 324.

Von Mueller, F. 1858. Tournefortia mollis. In: Fragm. (Mueller) 1: 59.

Zu Solms-Laubach, H.M.C.L.F. 1870. Die Familie der Lennoaceen. Abh. Naturf. Ges. Halle 11: 174. 